Sains Malaysiana 50(10)(2021): 3085-3094

http://doi.org/10.17576/jsm-2021-5010-21

\title{
Zingiber zerumbet (L.) Smith Hexane Crude Extract Caused DNA Damage on Leptospira spp.
}

(Ekstrak Mentah Heksana Zingiber zerumbet (L.) Smith Menyebabkan Kerosakan DNA pada Leptospira spp.)

\author{
FARAH WAHIDA IBRAHIM, NURUl Amirah ABDUl AZIZ, LATIFAH IBRAHIM, NuRUl FARHANA JUfRI \& ASMAH \\ HAMID*
}

ABSTRACT

Numerous attempts have been made to control leptospirosis by using chemoprophylaxis, but with limited success. The present study was done to investigate the antileptospiral potential of hexane, ethyl acetate and methanol extracts of Zingiber zerumbet rhizomes. The extracts were assayed for antileptospiral activity using broth microdilution method against Leptospira interrogans (serovar Batavie, Canicola, Australis) and Leptospira biflexa serovar Patoc. The Z. zerumbet hexane extract exhibited antileptospiral activity, with $I_{50}$ values of $248 \mu \mathrm{g} / \mathrm{mL}$ against $\mathrm{L}$. interrogans serovar Canicola, $I C_{50}$ of $125 \mu \mathrm{g} / \mathrm{mL}$ against $\mathrm{L}$. interrogans serovar Australis, $I_{50}$ of $15.63 \mu \mathrm{g} / \mathrm{mL}$ against $\mathrm{L}$. interrogans serovar Batavie and $I_{50}$ of $109 \mu \mathrm{g} / \mathrm{mL}$ against $\mathrm{L}$. biflexa serovar Patoc. However, both ethyl acetate and methanol extracts did not show any distinct antileptospiral activity. Since the hexane extract of Z. zerumbet showed antileptospiral activity, the DNA-damaging properties of this extract were tested according to their $I C_{50}$ and $I C_{25}$ values that were specific to each serovars. The DNA-damaging properties were determined by treating the selected Leptospira spp. with the hexane extract and subjecting its DNA to electrophoresis and analysis on agarose gels. The results demonstrated that the hexane extract had DNA-damaging properties towards L. biflexa serovar Patoc and L. interrogans serovar Australis, as proven by the appearance of fragmented DNA on the gels. We conclude that the Z. zerumbet hexane extract could inhibit the growth of Leptospira spp. serovar Patoc and Australis through DNA-damaging activity and thus, could be a potential antileptospiral agent. Further studies are needed to investigate the potential of this hexane extract as an antileptospiral agent using in vivo rat models of leptospirosis.

Keywords: Antileptospiral; DNA damage; growth inhibition; hexane crude extract; Zingiber zerumbet

ABSTRAK

Banyak usaha telah dibuat untuk mengawal leptospirosis dengan menggunakan kemoprofilaksis namun kejayaannya terhad. Penyelidikan ini dijalankan untuk mengkaji potensi antileptospira bagi ekstrak kasar heksana, etil asetat dan metanol rizom Zingiber zerumbet. Ekstrak telah diuji untuk aktiviti antileptospira menggunakan kaedah mikropencairan kaldu ke atas Leptospira interogans (serovar Batavie, Canicola, Australis) dan Leptospira biflexa serovar Patoc. Ekstrak heksana Z. zerumbet menunjukkan aktivti antileptospira dengan nilai IC ${ }_{50}$ pada $248 \mu \mathrm{g} / \mathrm{mL}$ terhadap L. interrogans serovar Canicola, IC $C_{50}$ pada $125 \mu \mathrm{g} / \mathrm{mL}$ terhadap L. interrogans serovar Australis, IC ${ }_{50}$ pada $15.63 \mu \mathrm{g} / \mathrm{mL}$ terhadap L. interrogans serovar Batavie dan $I_{50}$ pada $109 \mu \mathrm{g} / \mathrm{mL}$ untuk L. biflexa serovar Patoc. Walau bagaimanapun, kedua-dua ekstrak etil asetat dan metanol tidak menunjukkan sebarang aktiviti antileptospira yang ketara. Oleh kerana ekstrak heksana Z. zerumbet menunjukkan aktiviti antileptospira, keupayaan merosakkan DNA bagi ekstrak ini diuji mengikut nilai $I C_{50}$ dan $I_{25}$ khusus yang diperoleh untuk setiap serovar. Hasil kajian menunjukkan bahawa ekstrak heksana mempunyai keupayaan untuk merosakkan DNA L. biflexa serovar Patoc dan L. interrogans serovar Australis seperti yang terbukti dengan kehadiran DNA yang berfragmen pada gel. Sebagai kesimpulan, ekstrak heksana Z. zerumbet boleh menghalang pertumbuhan Leptospira spp. serovar Patoc dan Australis melalui aktiviti merosakkan DNA dan dengan itu, berpotensi sebagai agen antileptospira. Kajian lanjut diperlukan untuk mengkaji potensi ekstrak heksana sebagai agen antileptospira dalam model tikus leptospirosis secara in vivo.

Kata kunci: Antileptospira; ekstrak kasar heksana; kerosakan DNA; merencat pertumbuhan; Zingiber zerumbet 


\section{INTRODUCTION}

Leptospirosis is a bacterial infection caused by Leptospira. The genus Leptospira belongs to the phylum Spirochaetes and is divided into three types of species; saprophytic, intermediate and pathogenic (Paster et al. 1991; Schneider et al. 2018). Saprophytic leptospires, such as Leptospira biflexa, are free-living organisms found in water or soil and do not infect animal hosts (Faine et al. 1974). On the other hand, pathogenic strains of Leptospira infect animal hosts and humans such as Leptospira interrogans and Leptospira borgpetersenii (Picardeau et al. 2008). Intermediate Leptospira (for instance, Leptospira wolffii and Leptospira broomii) are not as virulent as the pathogenic species, but have been linked to human leptospirosis incidence (Arzouni et al. 2002). Leptospira are divided into numerous serovars (sub-species level) that could be distinguished by the characteristics of its antigens. Thirteen serogroups have been identified in Malaysia including Australis, Bataviae and Canicola (Bahaman \& Ibrahim 1988).

The incidence of leptospirosis in tropical countries is higher than the rest of the world and was reported to range from 10 to 100 human cases per 100,000 individuals (Guera 2013). Thus, leptospirosis has become a public health problem due to its potential to become an epidemic (Schneider et al. 2013). In Malaysia, an increasing trend of leptospirosis cases had been observed from 2004 to 2014. From 263 cases in 2004, the number had significantly increased to 7,806 cases in 2014 (Garba et al. 2017). Outbreaks were identified to be seasonal, peaking during the rainy seasons and may be associated with floods (Mohd Radi et al. 2018; Zaki et al. 2018).

Leptospirosis exhibits similar symptoms such as fevers that are common to many other tropical diseases, thus further complicating its early detection. Patients who have been infected are usually treated with antibiotic prophylaxis such as doxycycline (Muhammad Aklil et al. 2018). However, studies on antileptospiral activities of natural products, specifically herbs have gained more interests nowadays. Previously, the Adhatoda extract has been proven to damage the inclusion body and motility of $L$. interrogans serovar Louisiana, which led to the loss of the organism's virulence activity (Nelson et al. 2013). In another study, the aqueous extract of Quercus infectoria Gall was also reported to have antimicrobial activity against pathogenic Leptospira (Husna et al. 2018). The methanol leaves extract of Dabai (or Canarium odontophyllum), a native plant to Borneo Island, also showed promising antileptospiral activity (Shafariatul Akmar et al. 2019). Of particular interest, one of the identified potential herbal antileptospiral agents is Zingiber zerumbet, which is also known as Lempoyang among locals and belongs to the family of Zingiberaceae (Yob et al. 2011).

Z. zerumbet is known to have antimicrobial activity against important pathogenic bacteria that are commonly associated with HIV infection such as Staphylococcus aureus, methicillin-resistant Staphylococcus aureus, Streptococcus mutants, and Salmonella typhi (da Silva et al. 2018; Kader et al. 2011, 2010; Voravuthikunchai et al. 2005). It also has anti-staphylococcal activity against a series of multi-drug resistant (MDR) S. aureus strains (Kader et al. 2010). Although the antimicrobial activity of the $Z$. zerumbet extract on common bacterial infection in humans has been widely studied, its effect against Leptospira is still underexplored.

\section{MATERIALS AND METHODS}

SUBCULTURE OF Leptospira spp.

Leptospira samples used in this study were L. interrogans serovar Bataviae, Canicola, and Australis as well as $L$. biflexa serovar Patoc. All samples were subcultured into EMJH medium for storage purposes and stored in the dark at $27{ }^{\circ} \mathrm{C}$ to $30{ }^{\circ} \mathrm{C}$. All stock cultures of samples were supplied by the Biotechnology Unit, Institute for Medical Research, Kuala Lumpur, Malaysia.

\section{PREPARATION OF Z. zerumbet CRUDE EXTRACT}

The air-dried finely chopped rhizomes of $Z$. zerumbet (Specimen Voucher: UKMB-29952) were sequentially soaked at room temperature in hexane, ethyl acetate and methanol for 72 hours. The extracts were filtered and evaporated to dryness in vacuum to yield crude extracts of hexane, ethyl acetate, and methanol separately. All of the crude extracts were stored at $4{ }^{\circ} \mathrm{C}$ for further tests. Prior to use, the $Z$. zerumbet ethyl acetate extract was dissolved in dimethyl sulfoxide (DMSO) and diluted in phosphate buffered saline ( $\mathrm{pH}$ 7.4).

\section{PERCENT INHIBITION TEST (\%) OF Z. zerumbet CRUDE EXTRACTS}

Active Leptospira cultures were prepared in EMJH medium and grown at $30{ }^{\circ} \mathrm{C}$ for 7 days. For the assay, the density of Leptospira was determined based on turbidity by using a spectrophotometer at $280 \mathrm{~nm}$. The culture was then diluted in EMJH medium to reach a bacterial density of $2 \times 10^{6}$ cells $/ \mathrm{mL}$. Two-fold serial dilutions of the hexane, ethyl acetate and methanol crude extracts at concentrations ranging from 1.95 to $500 \mu \mathrm{g} / \mathrm{mL}$ were prepared in EMJH medium containing 10\% DMSO 
in a sterile 96-well round-bottomed plate, with the final volume of $10 \mu \mathrm{L}$ per well. A total of $190 \mu \mathrm{L}$ of inoculum containing $2 \times 10^{6}$ cells $/ \mathrm{mL}$ were transferred into each well. Each plate was prepared with blanks $(200 \mu \mathrm{L}$ of media EMJH without Leptospira), negative controls $(200 \mu \mathrm{L}$ of media EMJH containing $2 \times 10^{6}$ Leptospira) and positive controls $\left(200 \mu \mathrm{L}\right.$ of media EMJH containing $2 \times 10^{6}$ Leptospira and Doxycycline). The plates were wrapped with aluminium foil and incubated for 3 days at $30{ }^{\circ} \mathrm{C}$ in the dark. On the third day, the turbidity of the growth in the plate was determined spectrophotometrically at $280 \mathrm{~nm}$ wavelength. The percent inhibition of Leptospira growth by $Z$. zerumbet extracts was determined via the following formula (Wong et al. 2010):

Percent inhibition $(\%)=\frac{\mathrm{OD}_{\text {control }}-\mathrm{OD}_{\text {test }}}{\mathrm{OD}_{\text {control }}} \times 100$

where $\mathrm{OD}_{\text {test }}$ is the $\mathrm{OD} 280$ reading average for test sample, and $\mathrm{OD}_{\text {control }}$ is the OD280 reading average for control sample.

Percentage of inhibition is 0 or no inhibition if the results are negative. The test was conducted in triplicates for each serovar.

\section{DNA PREPARATION AND POLYMERASE CHAIN REACTION FOR Leptospira CONFIRMATION}

Active Leptospira cultures were prepared in EMJH medium and propagated at $30^{\circ} \mathrm{C}$ for 7 days. Each type of serovars was then sub-cultured into new EMJH medium containing $\mathrm{IC}_{25}$ of hexane extracts for $L$. interrogans serovar Bataviae and $\mathrm{IC}_{50}$ of hexane extracts for the other serovars. The inoculums were incubated for 7 days at $30{ }^{\circ} \mathrm{C}$ in the dark. Template genomic DNA was prepared using Invitek kit (STRATEC Molecular, Germany). Polymerase chain reaction (PCR) primers LA/LB ([5'-GGC
GGC GCG TCT TAAACA TG-3'] and [5'-TTC CCC CCA TTG AGC AAG ATT-3']), targeting the $16 \mathrm{~S}$ rDNA gene, were used to confirm the genus Leptospira (Benacer et al. 2013). The reactions were carried out in a thermocycler (Lab Cycler, SensoQuest, Germany). The cycling conditions consisted of an initial denaturation at $94{ }^{\circ} \mathrm{C}$ for $3 \mathrm{~min}$ followed by 35 cycles of denaturing at $94{ }^{\circ} \mathrm{C}$ for $1 \mathrm{~min}$, 35 cycles of annealing at $57^{\circ} \mathrm{C}$ for $1 \mathrm{~min}, 35$ cycles of elongation at $72{ }^{\circ} \mathrm{C}$ for $2 \mathrm{~min}$, and additional extension at $72{ }^{\circ} \mathrm{C}$ for $10 \mathrm{~min}$.

\section{EFFECT OF Z. zerumbet HEXANE EXTRACT ON Leptospira DNA}

The DNAs of treated L. interrogans serovar Bataviae, Canicola, Australis and L. biflexa serovar Patoc that were isolated and confirmed by PCR assay were mixed with loading buffer, electrophoresed at $100 \mathrm{~V}$ and visualized on $1.5 \%$ agarose gel containing ethidium bromide. The isolated treated DNAs were analyzed together with the DNAs of the untreated L. interrogans serovar Bataviae, Canicola, Australis and L. biflexa serovar Patoc, which served as controls. The resulting DNA fragment bands were further visualized and photographed using a gel documentation system (Biorad, Hercules, California, USA).

\section{RESULTS}

\section{CONFIRMATION OF Leptospira ISOLATES BY PCR WITH} SPECIFIC PRIMERS

All spirochete bacteria used in the current study produced PCR products with $331 \mathrm{bp}$-long fragments of the 16S rDNA gene, a diagnostic target for PCR-based detection of Leptospira spp. (Benacer et al. 2013, Mérien et al. 1992) (Figure 1).

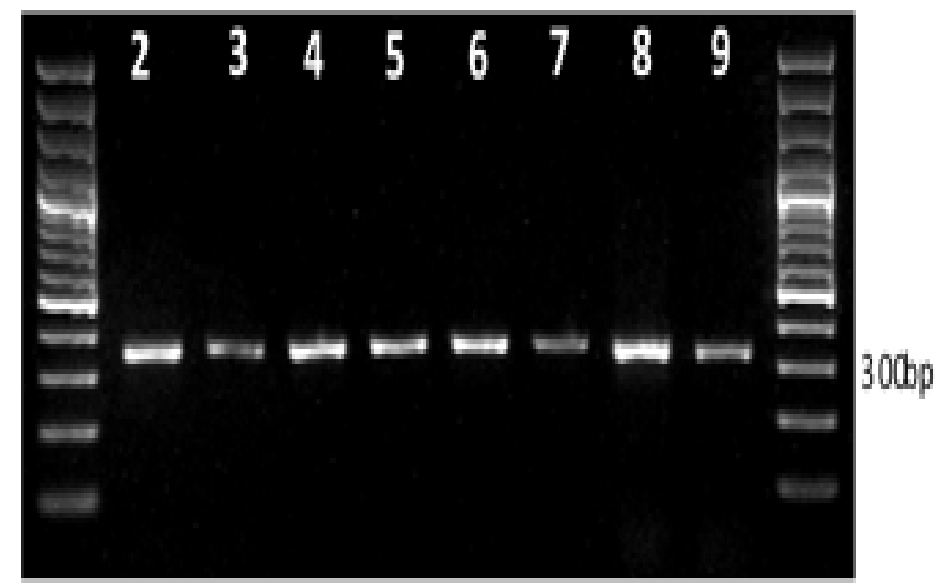

FIGURE 1. PCR product of primer LA/LB on DNA of Leptospira. Lane 1 and 10: DNA Ladder (100 bp), Lane 2 and 3: Bataviae (control and grown in $15.63 \mu \mathrm{g} / \mathrm{mL}$ hexane extract), Lane 4 and 5: Canicola (control and grown in $248 \mu \mathrm{g} / \mathrm{mL}$ hexane extract), Lane 6 and 7: Australis (control and grown in in $109 \mu \mathrm{g} / \mathrm{mL}$ hexane extract), Lane 8 and 9: Patoc (control and grown in in $125 \mu \mathrm{g} / \mathrm{mL}$ hexane extract) 
INHIBITORY ACTIVITY OF Z. zerumbet CRUDE EXTRACTS ON Leptospira GROWTH

In general, L. biflexia serovar Patoc was the only serovar studied which was affected by hexane, ethyl acetate and methanol extracts of $Z$. zerumbet as evidenced by the $50 \%$ growth inhibition (Table 1). At the same percent inhibition, both $L$. interrogans serovar Canicola and $L$. interrogans serovar Australis were susceptible only to the hexane extract of $Z$. zerumbet (more than $50 \%$ growth inhibition). Both ethyl acetate and methanol extracts either showed no inhibition or less than $10 \%$ growth inhibition activity against $L$. interrogans serovar Australis.

TABLE 1. Percentage of Leptospira growth inhibition (\%) in selected range of concentration $(\mu \mathrm{g} / \mathrm{mL})$ using different types of solvents

\begin{tabular}{|c|c|c|c|c|c|c|c|c|c|c|c|c|}
\hline \multirow{4}{*}{$\begin{array}{l}\text { Concentration of } \\
\text { Z. zerumbet crude } \\
\text { extracts } \\
(\mu \mathrm{g} / \mathrm{mL})\end{array}$} & \multicolumn{12}{|c|}{$\begin{array}{c}\text { Percentage of Leptospira growth inhibiton }(\%) \text { in selected range of concentration }(\mu \mathrm{g} / \mathrm{mL}) \text { using different } \\
\text { solvents }\end{array}$} \\
\hline & \multicolumn{12}{|c|}{ Leptospira's Serovar } \\
\hline & \multicolumn{3}{|c|}{$\begin{array}{l}\text { L. interrogans serovar } \\
\text { Bataviae }\end{array}$} & \multicolumn{3}{|c|}{$\begin{array}{l}\text { L. interrogans serovar } \\
\quad \text { Canicola }\end{array}$} & \multicolumn{3}{|c|}{$\begin{array}{l}\text { L. interrogans serovar } \\
\quad \text { Australis }\end{array}$} & \multicolumn{3}{|c|}{$\begin{array}{l}\text { L. biflexa } \\
\text { serovar Patoc }\end{array}$} \\
\hline & Hex & EA & Met & Hex & EA & Met & Hex & EA & Met & Hex & EA & Met \\
\hline 1.95 & - & - & - & - & - & - & - & - & - & - & - & - \\
\hline 3.91 & 22 & 5 & - & - & - & - & 25 & - & - & 30 & 37 & 39 \\
\hline 7.82 & 23 & 7 & - & - & 8 & - & 26 & - & - & 31 & 39 & 41 \\
\hline 15.63 & 25 & 10 & 19 & 6 & 28 & 4 & 31 & - & - & 32 & 56 & 44 \\
\hline 31.25 & 29 & 13 & 21 & 7 & 30 & 6 & 36 & - & - & 38 & 62 & 45 \\
\hline 62.5 & 32 & 15 & 28 & 40 & 35 & 27 & 45 & - & - & 42 & 67 & 45 \\
\hline 125 & 35 & 16 & 34 & 41 & 40 & 29 & 51 & - & 4 & 55 & 68 & 49 \\
\hline 250 & 37 & 18 & 37 & 51 & 45 & 29 & 53 & - & 7 & 60 & 69 & 54 \\
\hline 500 & 39 & 20 & 39 & 75 & 48 & 30 & 66 & - & 8 & 74 & 70 & 65 \\
\hline
\end{tabular}

Hex: hexane, EA: ethyl acetate, Met: methanol

Dose-response curves (Figure 2(A) - 2(D)) have been constructed to determine the concentration of $Z$. zerumbet extracts that can inhibit the growth of Leptospira tested at $10 \%, 25 \%$, and $50 \%$ growth inhibition. The hexane extract was found to have the median inhibitory concentration $\left(\mathrm{IC}_{50}\right)$ value or able to inhibit $50 \%$ of L. interrogans serovar Canicola and serovar Australis as well as L. biflexa serovar Patoc growth at the concentration of $248 \mu \mathrm{g} / \mathrm{mL}, 125 \mu \mathrm{g} / \mathrm{mL}$, and $109 \mu \mathrm{g} / \mathrm{mL}$, respectively (Table 2).

Both ethyl acetate and methanol extracts showed $\mathrm{IC}_{50}$ values of $13 \mu \mathrm{g} / \mathrm{mL}$ and $156.25 \mu \mathrm{g} / \mathrm{mL}$ for $L$. biflexa serovar Patoc, respectively. Meanwhile, for $L$. interrogans serovar Canicola, $\mathrm{IC}_{25}$ values of $13.69 \mu \mathrm{g} /$ $\mathrm{mL}$ and $61 \mu \mathrm{g} / \mathrm{mL}$ were observed for both ethyl acetate and methanol extracts, respectively. The methanol extract inhibited $25 \%$ growth of $L$. interrogans serovar Bataviae $\left(\mathrm{IC}_{25}\right)$ at the concentration of $46.88 \mu \mathrm{g} / \mathrm{mL}$, while the ethyl acetate extract was not active against this serovar. However, $25 \%$ of the bacterial growth $\left(\mathrm{IC}_{25}\right)$ of $L$. interrogans serovar Bataviae was inhibited by $15.63 \mu \mathrm{g} /$ $\mathrm{mL}$ hexane extract, though the inhibition was not dosedependent as exposure to higher concentrations of the hexane extract failed to achieve $50 \%$ inhibition against this serovar (Table 2). Unlike the other three Leptospira spp., the growth of $L$. interrogans serovar Australis was not affected by the ethyl acetate and methanol extract of $Z$. zerumbet. This was clearly evidenced by absence of inhibitory concentration values as shown in Figure 2(C) and tabulated in Table 2. 
A.

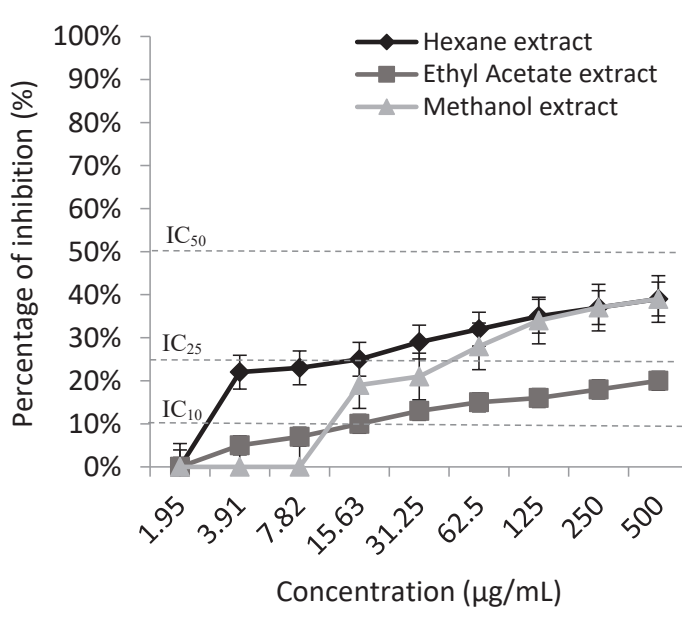

C.

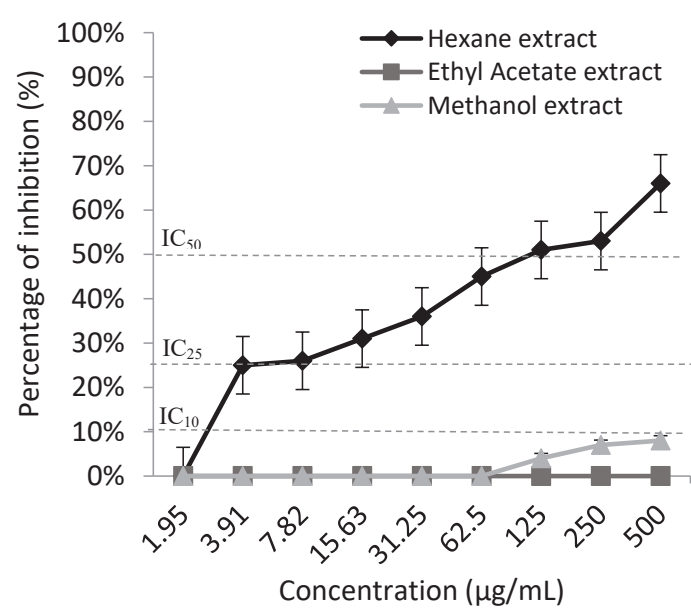

B.

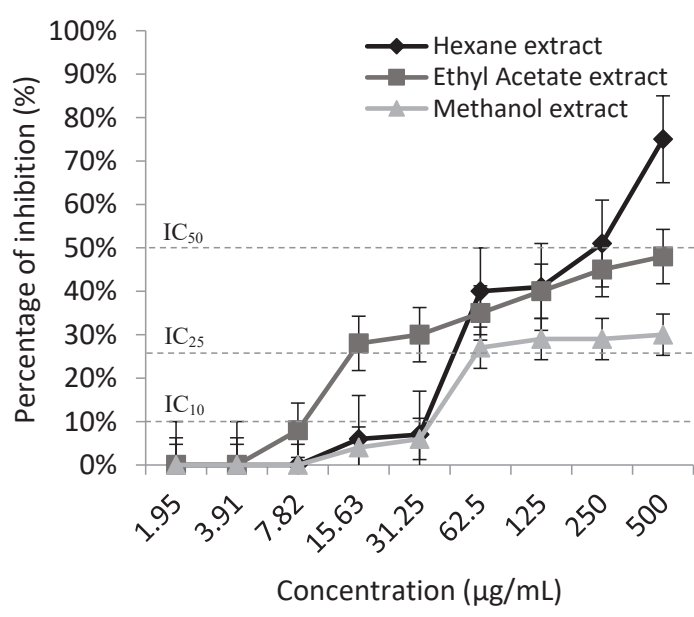

D.

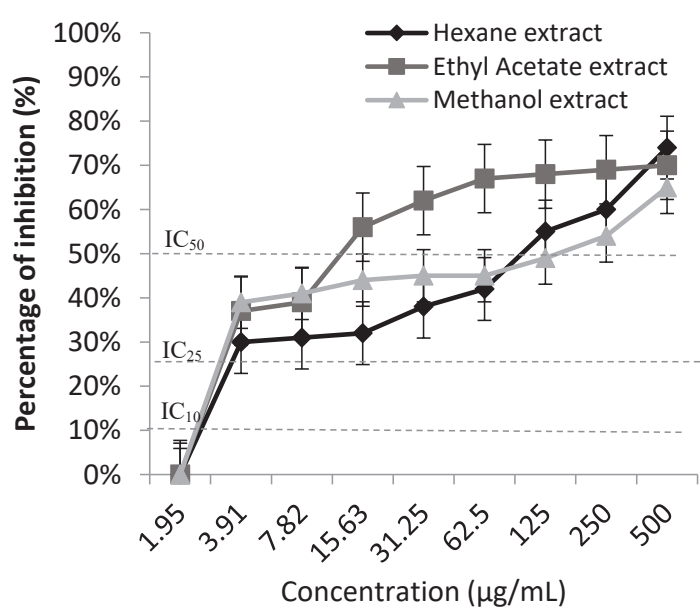

FIGURE 2. The growth inhibition concentration of hexane, ethyl acetate, and methanol extracts of Zingiber zerumbet on different Leptospira spp.; L. interrogans serovar Bataviae (A), B-L. interrogans serovar Canicola (B), L. interrogans serovar Australis (C) and $L$. biflexa serovar Patoc (D)

TABLE 2. The Leptospira spp. growth inhibitory concentrations of Z. zerumbet crude extracts $(\mu \mathrm{g} / \mathrm{mL})$ at $10 \%, 25 \%$ and $50 \%$

\begin{tabular}{|c|c|c|c|c|c|c|c|c|c|c|c|c|c|}
\hline \multirow{4}{*}{ 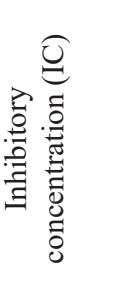 } & \multirow{4}{*}{ 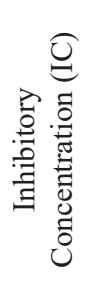 } & \multicolumn{12}{|c|}{ Inhibitory concentration values of $Z$. zerumbet crude extracts $(\mu \mathrm{g} / \mathrm{mL})$} \\
\hline & & \multicolumn{12}{|c|}{ Leptospira's Serovar } \\
\hline & & \multicolumn{3}{|c|}{$\begin{array}{c}\text { L. interrogans serovar } \\
\text { Bataviae }\end{array}$} & \multicolumn{3}{|c|}{$\begin{array}{c}\text { L. interrogans serovar } \\
\text { Canicola }\end{array}$} & \multicolumn{3}{|c|}{$\begin{array}{c}\text { L. interrogans serovar } \\
\text { Australis }\end{array}$} & \multicolumn{3}{|c|}{$\begin{array}{c}\text { L. biflexa } \\
\text { serovar Patoc }\end{array}$} \\
\hline & & Hex & EA & Met & Hex & EA & Met & Hex & EA & Met & Hex & EA & Met \\
\hline $\mathrm{IC}_{10}$ & & 2.93 & 15.63 & 11.73 & 34 & 8 & 2.44 & 2.93 & - & - & 2.44 & 2.44 & 2.44 \\
\hline $\mathrm{IC}_{25}$ & & 15.63 & - & 46.88 & 47 & 13.69 & 61 & 3.91 & - & - & 3.66 & 3.42 & 3.42 \\
\hline $\mathrm{IC}_{50}$ & & - & - & - & 248 & - & - & 125 & - & - & 109 & 13 & 156.25 \\
\hline
\end{tabular}

Hex: hexane, EA: ethyl acetate, Met: methanol 
GENOMIC DNA-DAMAGING EFFECT OF Zingiber zerumbet EXTRACTS

The genomic DNA extracted from $L$. interrogans serovar Bataviae and serovar Canicola was exposed to $15.63 \mu \mathrm{g} / \mathrm{mL}$ (Figure 3(A)) and $248 \mu \mathrm{g} / \mathrm{mL}$ (Figure 3(B)) of hexane extracts, respectively, and was shown to be all intact, comparable to the untreated genomic DNA. However, when compared to the untreated DNA of $L$. interrogans serovar Australis (control), the treatment of $Z$. zerumbet hexane extract at $125 \mu \mathrm{g} / \mathrm{mL}$ caused fragmentation to the bacterial genomic DNA (Figure 4(A)). Subculturing of L. biflexa serovar Patoc with the $\mathrm{IC}_{50}$ concentration of $Z$. zerumbet hexane extract (109 $\mu \mathrm{g} / \mathrm{mL}$ ) showed fragments of DNA being produced, indicating DNA-damaging effects of the hexane extract (Figure 4(B)).

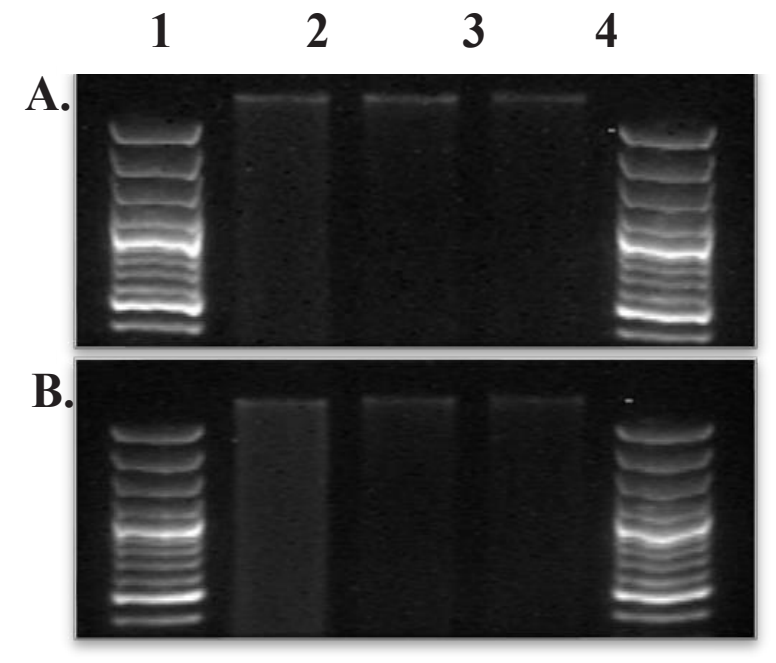

FIGURE 3. The effect of $Z$. zerumbet hexane extract on the DNA of Leptospira spp. The Leptospira was grown in EMJH media with $15.63 \mu \mathrm{g} / \mathrm{mL}$ of hexane extract against $L$. interrogans serovar Bataviae (A) and $248 \mu \mathrm{g} / \mathrm{mL}$ hexane extract against $L$. interrogans serovar Canicola (B) for 7 days before the DNA was extracted and electrophoresed. Lane 1 and 5: DNA

ladder (100 bp), Lane 2: Normal DNA, Lane 3 and 4: Leptospira with hexane extract

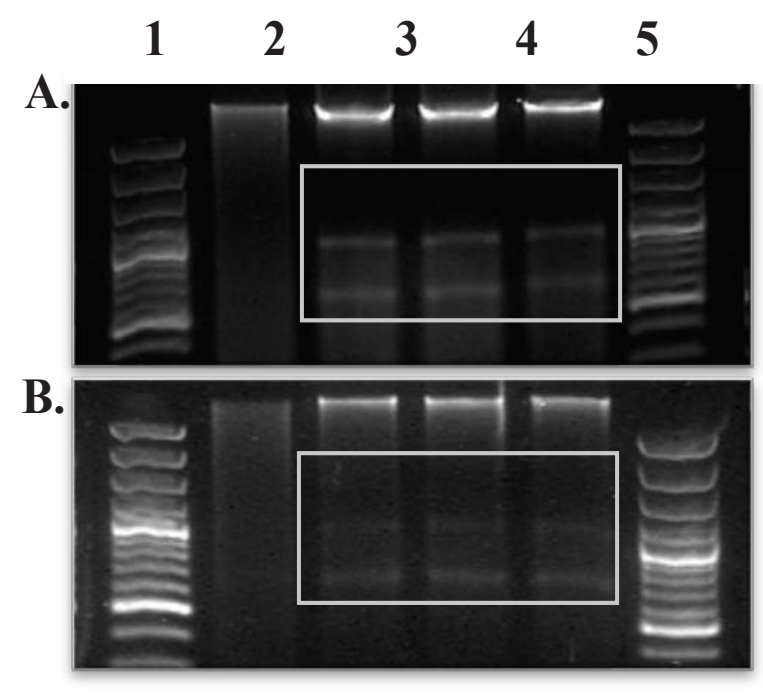

FIGURE 4. The effect of $Z$. zerumbet hexane extract on the DNA of Leptospira spp. The Leptospira was grown in EMJH media with $125 \mu \mathrm{g} / \mathrm{mL}$ against $L$. interrogans serovar Australis (A) and with $109 \mu \mathrm{g} / \mathrm{mL}$ hexane extract against L. biflexa serovar Patoc for 7 days before the DNA was extracted and electrophoresed. Note the presence of fragmented DNA as indicated in the white box in Lane 3-5 of both Figure 4(A) and 4(B). Lane 1 and 6 :

DNA ladder, Lane 2: Normal DNA, Lane 3, 4 and 5: Leptospira with hexane extract 


\section{DISCUSSION}

In the current study, the LA/LB $16 \mathrm{~S}$ rDNA primers were used to identify the Leptospira isolates via PCR. The presence of bands at $331 \mathrm{bp}$ demonstrated the extracted DNA was of Leptospira origin (Benacer et al. 2013). The pathogenicity status of Leptospira spp. could be further confirmed by detecting the expression of lipoprotein LipL32 protein (a virulence factor) via PCR (Dive et al. 1987; Latifah et al. 2017). This particular protein is highly expressed in Leptospira during fatal acute infections compared to in vitro culture (Nally et al. 2007). Although the pathogenicity of the Leptospira spp. used in the current study was not determined, though the pathogenicity of the original stocks has been confirmed. Furthermore, previous reports have stated that $L$. interrogans is a pathogenic species whilst $L$. biflexia is saprophytic (Benacer et al. 2016; Evangelista \& Coburn 2010; Saengjaruk et al. 2007).

The aim of the study was to investigate the antileptospiral activity of three different Zingiber zerumbet extracts, which were hexane, ethyl acetate, and methanol. Based on the percent inhibition results, each tested extract showed different inhibitory activities to different Leptospira serovars. Similarly, a study conducted by Murray and Hospenthal (2004) also showed the diverse susceptibilities of 12 different Leptospira serovars towards three common antibiotics used in the treatment of leptospirosis: penicillin, doxycycline and chloramphenicol. Their study showed that the currently used antibiotics have different inhibitory concentrations against selected Leptospira spp. The diversity of response of Leptospira spp. towards different treatments and doses used could be explained by the lipopolysaccharide expressions on the surface of the bacteria (Adler et al. 2010), or could be due to the formation of biofilms (Vinod et al. 2018).

Furthermore, the differences in the inhibitory responses shown by the Leptospira spp. used in the current study could also be attributed to the presence of different active compounds in each of the extraction solvent used. The types and amounts of phytochemical compounds in the crude extracts depend on the polarity of the solvent used for extraction. Among the three solvents used, methanol was the most polar whilst hexane was the least. In the current study, the hexane extract showed more effective inhibitory activities as proven by the $\mathrm{IC}_{50}$ values against all selected Leptospira spp. compared to the limited effectiveness of methanol and ethyl acetate extracts. Although the inhibition was not total (100\% inhibition), the fact that the hexane extract could inhibit $50 \%$ growth of the pathogenic $L$. interrogans strains used in the current study showed that it has great potential as antileptospiral agent. Further investigation showed that only L. interrogans serovar Australis exhibited DNA damage upon exposure to Z. zerumbet hexane extract at $125 \mu \mathrm{g} / \mathrm{mL}$ compared to serovar Canicola that was exposed to double the concentration of similar solvent extract. The results suggest that there could be other mechanism besides bacterial DNA damage that induced bacterial growth inhibition in L. interrogans serovar Canicola. The primary modes of action of therapeutic agents generally used in the treatment of leptospirosis include inhibiting the synthesis of nucleic acid, protein and bacterial cell wall; altering the bacterial cell membrane or having antimetabolite activity.

Despite the fact that L. biflexa serovar Patoc is a saprophytic strain and non-pathogenic, this bacterium was vulnerable towards all three $Z$. zerumbet extracts used in this study. Among the three solvents used, ethyl acetate extract was the only extract that could inhibit $50 \%$ of the growth of this bacterium and at the lowest concentration compared to the other two solvents. Furthermore, at an $\mathrm{IC}_{50}$ of $109 \mu \mathrm{g} / \mathrm{mL}$, the hexane extract of $Z$. zerumbet was also shown to cause DNA damage to L. biflexa serovar Patoc, similar to the effect of the hexane extract towards L. interrogans serovar Australis.

The results of the current study focused more on the effect of the hexane extract rather than the other two solvent extracts as this particular extract was shown to be active against all of the Leptospira spp. investigated in this study. This shows that the hexane extract is more practical to be developed as an antileptospiral agent due to its broader spectrum. Hexane is a non-polar solvent known to extract lipophilic compounds (Musa et al. 2015). Lipophilicity of an antibacterial compound is an important characteristic as it can determine the success or failure of the compound to access its target (Echeverría et al. 2017).

According to Patial et al. (2019), among the phytochemical constituents obtained using the soxhlet extraction method with hexane as a solvent are triterpenoids, glycosides and steroids. Plant-based terpenoid, flavanoid and steroid compounds are commonly associated with antimicrobial and antiinflammatory activities (Cushnie \& Lamb 2005; Patel \& Saviani 2015; Prakash 2017). Zerumbone, a sesquiterpenoid that is lipophilic in nature, is the main bioactive compound present in the rhizomes of $Z$. zerumbet (L.) Smith. The reported activities of zerumbone that have merits and relevant to the findings of the current study are antimicrobial and antiinflammatory activities (Abdul et al. 2008; Haque et al. 
2018). Doxycycline, one of the antibiotics used for the treatment of leptospirosis is both antibacterial and antiinflammatory. This dual characteristic is beneficial and more effective as a therapeutic agent as Leptospira may induce overexpression of inflammatory responses that are often associated with poor prognosis of leptospirosis (Matsui et al. 2011; Zhang et al. 2017). Furthermore, $Z$. zerumbet crude extracts have also been shown to be neuroprotective, hepatoprotective, and nephroprotective against pathological-induced conditions (Abdul Hamid et al. 2012; Hamid et al. 2018, 2011), thus the usage might be able to delay functional deterioration of affected organs in leptospirosis.

\section{CONCLUSION}

The hexane extract of $Z$. zerumbet was found to have a broader antileptospiral activity compared to ethyl acetate and methanol extracts. The hexane extract was also shown to cause damage to the DNA of $L$. interrogans serovar Australis, which is one of the pathogenic serovars of Leptospira spp. Based on the results of the two tests, it was found that the hexane extract of $Z$. zerumbet has the potential to be developed as an antileptospiral agent in the future. To achieve this, future work should focus on investigating both antileptospiral and anti-inflammatory activities of the Zingiber zerumbet hexane crude extract of the rhizomes using the in vivo model of leptospirosisinduced rats.

\section{ACKNOWLEDGEMENTS}

We are thankful to the Biotechnology Unit, Institute for Medical Research, Kuala Lumpur for providing the Leptospira spp. samples as well as providing us with the laboratory facilities to partially conduct the research.

\section{REFERENCES}

Abdul, A., Siddiq, I.A., Adel, S.A., Manal, M.E. \& Syam, M.M. 2008. Anti-cancer and anti-microbial activities of zerumbone from the rhizomes of Zingiber zerumbet. Int. J. Pharm. 4(4): 301-304.

Abdul Hamid, Z., Budin, S.B., Ng, W.J., Hamid, A., Husain, K. \& Mohamed, J. 2012. Nephroprotective effects of Zingiber zerumbet Smith ethyl acetate extract against paracetamolinduced nephrotoxicity and oxidative stress in rats. $J$. Zhejiang Univ. Sci. B 13(3): 176-185.

Adler, B. \& de la Pena Moctezuma, A. 2010. Leptospira and leptospirosis. Vet. Microbiol. 140(3-4): 287-296.

Arzouni, J.P., Parola, P., La Scola, B., Postic, D., Brouqui, P. \& Raoult, D. 2002. Human infection caused by Leptospira fainei. Emerg. Infect. 2002: 865-868.
Bahaman, A.R. \& Ibrahim, A.L. 1988. A review of leptospirosis in Malaysia. Vet. Res. Commun. 12(2): 179-189.

Benacer, D., Siti, N.M.Z., Zhu Sim, S., Nizam, M.K.M.K., Galloway, R.L., Souris, M. \& Thong, K.L. 2016. Determination of Leptospira borgpetersenii serovar Javanica and Leptospira interrogans serovar Bataviae as the persistent Leptospira serovars circulating in the urban rat populations in Peninsular Malaysia. Parasit Vectors 9: 117.

Benacer, D., Who, P.Y., Mohd Zain, S.N., Amran, F. \& Thong, K.L. 2013. Pathogenic and saprophytic Leptospira species in water and soils from selected urban sites in Peninsular Malaysia. Microbes. Environ. 28(1): 135-140.

Cushnie, T.P. \& Lamb, A.J. 2005. Antimicrobial activity of flavonoids. Int. J. Antimicrob. Agents 26(5): 343-356.

da Silva, T.M., Pinheiro, C.D., Orlandi, P.P., Pinheiro, C.C. \& Pontes, G.S. 2018. Zerumbone from Zingiber zerumbet (L.) Smith: A potential prophylactic and therapeutic agent against the cariogenic bacterium Streptococcus mutans. BMC Complement Altern. Med. 18: 301.

Dive, A.M., Bigaignon, G. \& Reynaert, M. 1987. Adult respiratory distress syndrome in leptospira icterohaemorrhagiae infection. Intensive Care Med. 13(3): 214.

Echeverría, J., Opazo, J., Mendoza, L., Urzúa, A. \& Wilkens, M. 2017. Structure-activity and lipophilicity relationships of selected antibacterial natural flavones and flavanones of Chilean flora. Molecules 22(4): E608. doi: 10.3390/ molecules22040608.

Evangelista, K.V. \& Coburn, J. 2010. Leptospira as an emerging pathogen: A review of its biology, pathogenesis and host immune responses. Future Microbiol. 5(9): 1413-1425.

Faine, S., Adler, B. \& Ruta, G. 1974. A mechanism of immunity to leptospirosis. Aust. J. Exp. Biol. Med. Sci. 52(2): 301-310.

Garba, B., Bahaman, A.R., Khairani-Bejo, S., Zakaria, Z. \& Mutalib, A.R. 2017. Retrospective study of leptospirosis in Malaysia. EcoHealth 14(2): 389-398.

Guerra, M.A. 2013. Leptospirosis: Public health perspectives. Biologicals 41(5): 295-297.

Hamid, A., Ibrahim, F.W., Teoh, H.M., Nasrom, M.N., Eusoff, N., Husain, K. \& Abdul Latif, M. 2018. Zingiber zerumbet L. (Smith) extract alleviates the ethanol-induced brain damage via its antioxidant activity. BMC Complement Altern. Med. 18(1): 101

Hamid, A., Budin, S.B., Mohamed, R.A.P., Manaf, N.A., Yuhana, N.Y., Husain, K., Abd Hamid, Z. \& Mohamed, J. 2011. Role of oxidative stress in the protective effects of Zingiber zerumbet Smith ethyl-acetate extract against paracetamolinduced hepatotoxicity in Sprague-Dawley rat. Aust. J. Basic Appl. Sci. 5(8): 1519-1525.

Haque, M.A., Jantan, I. \& Harikrishnan, H. 2018. Zerumbone suppresses the activation of inflammatory mediators in LPS-stimulated U937 macrophages through MyD88dependent NF-אB/MAPK/PI3K-Akt signaling pathways. Int. Immunopharmacol. 55: 312-322.

Husna, M., Nabilah, I. \& Wan Nor Amilah, W.A.W. 2018. Anti-microbial activity of aqueous Quercus infectoria gall extract against pathogenic Leptospira. Malays. J. Med. Sci. 25(4): $42-50$ 
Kader, G., Nikkon, F., Rashid, M.A. \& Yeasmin, T. 2011. Antimicrobial activities of the rhizome extract of Zingiber zerumbet Linn. Asian Pac. J. Trop. Biomed. 1(5): 409-412.

Kader, M.G., Habib, M.R., Nikkon, F., Yeasmin, T., Rashid, M.A., Rahman, M.M. \& Gibbons, S. 2010. Zederone from the rhizomes of Zingiber zerumbet and its anti-staphylococcal activity. Boletín Latinoamericano y del Caribe de Plantas Medicinales y Aromáticas 9(1): 63-68.

Latifah, I., Abdul Halim, A., Rahmat, M.S., Faten, N.M., Ubil, Z.E., Asmah, H., Shafariatul Akmar, I., Picardeau, M., Siti Haslina, O. \& Nasir, M.A. 2017. Isolation by culture and PCR identification of LipL32 gene of pathogenic Leptospira spp. in wild rats of Kuala Lumpur. Malays. J. Pathol. 39(2): 161-166.

Matsui, M., Rouleau, V., Bruyère-Ostells, L. \& Goarant, C. 2011. Gene expression profiles of immune mediators and histopathological findings in animal models of leptospirosis: Comparison between susceptible hamsters and resistant mice. Infect. Immun. 79: 4480-4492.

Mérien, F., Amouriaux, P., Perolat, P., Baranton, G. \& Saint Girons, I. 1992. Polymerase chain reaction for detection of Leptospira spp. in clinical samples. J. Clin. Microbiol. 30(9): 2219-2224.

Mohd Radi, M.F., Hashim, J.H., Jaafar, M.H., Hod, R., Ahmad, N., Nawi, M., Baloch, G.M., Ismail, R. \& Farakhin Ayub, N.I. 2018. Leptospirosis outbreak after the 2014 major flooding event in Kelantan, Malaysia: A spatial-temporal analysis. Am. J. Trop. Med. Hyg. 98(5): 1281-1295.

Muhammad Aklil, A.R., Aznida, M.Z., Azman, A., Muhammad Haneef, A., Shaifuddin, N.H., Syed Syarizman, S.A.R., Mohammad Safree, J., Norfazilah, A. \& Mohd Rohaizat, H. 2018. Effectiveness of antibiotic prophylaxis for leptospirosis among adults: A systematic review. Malays. $J$. Appl. Sci. 3(2): 46-56.

Murray, C.K. \& Hospenthal, D.R. 2004. Determination of susceptibilities of 26 Leptospira sp. serovars to 24 antimicrobial agents by a broth microdilution technique. Antimicrob. Agents Chemother. 48(10): 4002-4005.

Musa, A.M., Ibrahim, M.A., Aliyu, A.B., Abdullahi, M.S., Tajuddeen, N., Ibrahim, H. \& Oyewale, A.O. 2015. Chemical composition and antimicrobial activity of hexane leaf extract of Anisopus mannii (Asclepiadaceae). J. Intercult. Ethnopharmacol. 4(2): 129-133.

Nally, J.E., Whitelegge, J.P., Bassilian, S., Blanco, D.R. \& Lovett, M.A. 2007. Characterization of the outer membrane proteome of Leptospira interrogans expressed during acute lethal infection. Infect. Immun. 75(2): 766-773.

Nelson, J., Chairman, K., Ranjit Singh, A.J.A., Padmalatha, C. \& Hepsibah, B. 2013. Cytomorphological changes and inhibition of inclusion body formation in Leptospira Interrogans on treatment with the extracts of Adhatodavasica. Adv. Tech. Biol. Med. 1(1): 1-4

Paster, B.J., Dewhirst, F.E., Weisburg, W.G., Tordoff, L.A., Fraser, G.J., Hespell, R.B., Stanton, T.B., Zablen, L., Mandelco, L. \& Woese, C.R. 1991. Phylogenetic analysis of the spirochetes. J. Bacteriol. 173(19): 6101-6109.
Patel, S.S. \& Savjani, J.K. 2015. Systematic review of plant steroids as potential antiinflammatory agents: Current status and future perspectives. J. Phytopharmacol. 4(2): 121-125.

Patial, P.K., Sharma, A., Kaur, I. \& Cannoo, D.S. 2019. Correlation study among the extraction techniques, phytochemicals, and antioxidant activity of Nepeta spicata aerial part. Biocatalysis and Agricultural Biotechnology 20: 101275

Picardeau, M., Bulach, D.M., Bouchier, C., Zuerner, R.L., Zidane, N., Wilson, P.J., Creno, S., Kuczek, E.S., Bommezzadri, S., Davis, J.C., McGrath, A., Johnson, M.J., Boursaux-Eude, C., Seemann, T., Rouy, Z., Coppel, R.L., Rood, J.I., Lajus, A., Davies, J.K., Médigue, C. \& Adler, B. 2008. Genome sequence of the saprophyte Leptospira biflexa provides insights into the evolution of Leptospira and the pathogenesis of leptospirosis. PLoS ONE 3(2): e1607.

Prakash, V. 2017. Terpenoids as source of anti-inflammatory compounds. Asian J. Pharm. Clin. Res. 10(3): 68-76.

Saengjaruk, P., Sakolvaree, Y., Maneewatch, S., Tomanakan, K., Tongtawe, P., Tapchaisri, P. \& Chaicumpa, W. 2007. Components of pathogenic Leptospira spp. with potentials for diagnosis of human leptospirosis. Asian Pac. J. Allergy Immunol. 25(4): 225-232.

Schneider, A.G., Casanovas-Massana, A., Hacker, K.P., Wunder, E.A.J., Begon, M., Reis, M.G., Childs, J.E., Costa, F., Lindow, J.C. \& Ko, A.I. 2018. Quantification of pathogenic Leptospira in the soils of a Brazilian urban slum. PLoS Negl. Trop. Dis. 12(4): e0006415.

Schneider, M.C., Jancloes, M., Buss, D.F., Aldighieri, S., Bertherat, E., Najera, P., Galan, D.I., Durski, K. \& Espinal, M.A. 2013. Leptospirosis: A silent epidemic disease. Int. $J$. Environ. Res. Public Health 10(12): 7229-7234.

Shafariatul Akmar, I., Syahirah, S., Fifi Fariza, A., Asmah, H., Latifah, I. \& Dayang Fredalina, B. 2019. In vitro antileptospiral activity of Canarium odontophyllum Miq. (Dabai) leaves extract. Malays. J. Microb. 15(3): 220-225.

Vinod, K.K., Lall, C., Vimal, R.R., Vedhagiri, K., Sunish, I.P. \& Vijayachari, P. 2018. Can subminimal inhibitory concentrations of antibiotics induce the formation of biofilm in Leptospira? Microb. Drug Resist. 24(7): 10401042.

Voravuthikunchai, S.P., Phongpaichit, S. \& Subhadhirasakul, S. 2005. Evaluation of antibacterial activities of medicinal plants widely used among aids patients in Thailand. Pharm. Biol. 43(8): 701-706.

Wong, S.K., Lim, Y.Y. \& Chan, E.W.C. 2010. Evaluation of antioxidant, anti-tyrosinase and antibacterial activities of selected Hibiscus species. Etnobotanical Leaflets 14: 781796.

Yob, N.J., Jofrry, S.M., Affandi, M.M.L.K., Salleh, M.Z. \& Zakaria, Z.A. 2011. Zingiber zerumbet (L.) Smith: A review of its ethnomedicinal, chemical, and pharmacological uses. Evid. Based Complement Alternat. Med. 2011: 543216.

Zaki, A.M., Rahim, M.A.A., Azme, M.H., Mahmood, N.A., Jeffree, M.S., Ghazi, H.F. \& Hassan, M.R. 2018. Animal reservoirs for Leptospira spp. in South-East Asia: A metaanalysis. J. Adv. Res. Med. 5(3): 23-31. 
Zhang, W., Xie, X., Wu, D., Jin, X., Liu, R., Hu, X., Fu, Y., Ding, Z., Zhang, N. \& Cao, Y. 2017. Doxycycline attenuates leptospira-induced il-1 $\beta$ by suppressing nlrp3 inflammasome priming. Front Immunol. 8: 857.

Farah Wahida Ibrahim, Nurul Amirah Abdul Aziz, Nurul Farhana Jufri \& Asmah Hamid*

Center for Toxicology and Health Risk Studies (CORE)

Faculty of Health Sciences

Universiti Kebangsaan Malaysia

Jalan Raja Muda Abdul Aziz

50300 Kuala Lumpur, Federal Territory

Malaysia
Latifah Ibrahim

Biotechnology Unit

Institute for Medical Research, Jalan Pahang

50588 Kuala Lumpur, Federal Territory

Malaysia

*Corresponding author; email: asmah0901@ukm.edu.my

Received: 25 March 2020

Accepted: 18 February 2021 